\title{
FASILITAS DAN AKSES YANG MEMPENGARUHI KEPUTUSAN KONSUMEN DALAM MEMNENTUKAN PEMBELIAN PERUMAHAN GRIYA AGUNG PERMATA BABAT LAMONGAN
}

\author{
Miftahul Huda \\ Ade Hanno W \\ miftahulhuda@unisda.ac.id \\ ade_hanno@gmail.com \\ Fakultas Ekonomi Universitas Islam Darul Ulum Lamongan
}

\begin{abstract}
Every company in marketing certain products implement a wide variety of marketing strategies. Marketing activities essentially focused on products, pricing, and distribution policy of promotion way.The purpose of this study was to investigate about the product attributes of housing facilities and access to consumer decisions.Allegedly facilities as well as access to housing has a role to consumer decision to purchase products Griya Agung Permata Babat Lamongan.From the research that has been tested with a sample of 100 respondents, showed that the F-test analysis results obtained $F$ count of 17.392 was the value of $F$ table at 2.70 so variable facilities (X1) and access to housing (X2) together have a real impact on consumer decision $(Y)$ is variable T test facility $(X 1)$ Calculate the value of 2,868 T> T Table of 1.660, $t$ test access to housing (X2) obtained amounted to 3.561 Calculate T> T Table of 1,660.Dari value of two variables the variable access to housing has a more dominant role than the facility with the highest variable T (3.561> 2.868).Based on the research results for the company should pay more attention factor, especially access to housing facilities as its own appeal for consumer.
\end{abstract}

Keywords: facilities, access to housing and consumer decisions

Abstrak: Setiap perusahaan dalam memasarkan produknya tertentu menerapkan berbagai macam strategi pemasaran. Kegiatan pemasaran pada intinya memfokuskan diri pada produk, penerapan harga, kebijakkan distribusi dan cara promosi.Tujuan penelitian ini adalah meneliti tentang atribut produk yakni tentang fasilitas dan akes perumahan terhadap keputusan konsumen. Diduga fasilitas maupun akses perumahan memiliki peranan terhadap keputusan konsumen dalam melakukan pembelian produk perumahan Griya Agung Permata Babat Lamongan.Dari hasil penelitian yang sudah di uji dengan sampel 100 responden, diperoleh hasil bahwa Uji F hasil analisis di peroleh F Hitung sebesar 17,392 sedang nilai F Tabel sebesar 2,70 jadi variabel fasilitas (X1) dan akses perumahan (X2) secara bersamasama memiliki pengaruh yang nyata terhadap keputusan konsumen (Y) sedang Uji $\mathrm{T}$ variabel fasilitas (X1) nilai $\mathrm{T}$ Hitung sebesar 2,868 > T Tabel sebesar 1,660, Uji T akses perumahan (X2) diperoleh T Hitung sebesar 3,561> nilai T Tabel sebesar 1,660.Dari dua variabel tersebut variabel akses perumahan memiliki peran yang lebih dominan dibandingkan dengan variabel fasilitas dengan nilai $\mathrm{T}(3,561>2,868)$. Berdasar hasil penelitian maka bagi perusahaan hendaknya lebih memperhatikan faktor fasilitas terutama akses perumahan sebagai daya tarik sendiri bagi para konsumen.

Kata Kunci : fasilitas , akses perumahan dan keputusan konsumen 


\section{PENDAHULUAN}

Dalam menghadapi era perdagangan bebas kini setiap perusahaan mengubah format strategi dan taktik pemasaran salah satunya berorientasi pada bagaimana membangun perusahaan yang kuat. Oleh karena itu, perusahaan harus mengembangkan cara pemasarannya agar tetap bertahan ditengah-tengah gelombang persaingan untuk memasuki pasar yang cukup tinggi. Dan satu yang tidak boleh dilupakan oleh perusahaan adalah konsumen, perlu disadari bahwa perubahan gaya hidup saat ini menyebabkan konsumen juga mempunyai cara sendiri dalam memenuhi kebutuhannya

Setiap perusahaan dalam memasarkan produknya tertentu menerapkan berbagai macam strategi pemasaran. Kegiatan pemasaran pada intinya memfokuskan diri pada produk, penerapan harga, kebijakkan distribusi dan cara promosi, yang dalam hal ini dikenal sebagai bauran pemasaran. Kegiatan pemasaran tentunya membutuhkan suatu strategi dan taktik. Strategi dan taktik ini tentu harus mampu memberikan kontribusi terhadap pencapaian tujuan perusahaan yaitu peningkatan penjualan.

Bauran pemasaran (marketing mix) adalah variabel-variabel pemasaran yang meliputi produk, promosi, harga, saluran distribusi, dan unsur-unsur lain dari bauran pemasaran, pada dasarnya sama yang ada pada setiap perusahaan. Bauran pemasaran adalah suatu strategi pemasaran untuk setiap perusahaan dapat mencapai pangsa pasar yang diinginkan, dengan biaya lebih tinggi tetapi berharap memperoleh pangsa pasar dan penghasilan lebih besar.

Tak bisa dipungkiri bahwa perumahan merupakan salah satu kebutuhan pokok manusia, dan kebutuhan akan perumahan pun semakin meningkat hal ini merupakan lahan bisnis yang sangat menjanjikan, sehingga banyak investor yang tertarik masuk kedalam lingkaran bisnis ini, oleh karena itu perusahaan perlu strategi khusus agar tetap bisa bertahan.

Keberhasilan suatu perusahan dalam pesaingan bisnis yang semakin ketat dapat dilihat dari seberapa besar perusahaan mampu menggaet konsumen dan mempertahankan konsumen agar tetap menggunakan atau mengkonsumsi produk dari perusahaan tersebut. Demikian pula halnya dengan Permahan Griya Agung Permata Babat Lamongan yang tentunya memerlukan strategi dan taktik yang tepat, guna meningkatkan Penjualan produknya, yaitu dengan memperhatikan aspek atribut produk (Winardi, 2008 :56).

Perumahan murah dengan konsep yang indah sebagai hunian yang nyaman dan juga memiliki nilai investasi. Perumahan Griya Agung Permata (AGP) yang berlokasi di Babat, Lamongan ini berada pada lokasi yang strategis. Dekat dengan sekolah, masjid, hotel, dan pasar agrobisnis. Bagi keluarga yang menginginkan kenyamanan dan juga sekaligus juga mengikuti lifestyle modern dengan balutan lingkungan hidup, maka AGP lah pilihan tepatnya.

Perumahan ini memiliki konsep yang menjadikan lingkungan hidup sebagai nilai penting untuk diindahkan, sehingga dengan begitu kenyamanan akan selalu terwujud. Di perumahan AGP ini ada lima tipe rumah yaitu tipe 85 dengan luas tanah $9 \times 14 \mathrm{~m}$, tipe 75 dengan luasan tanah $9 \times 14 \mathrm{~m}$, tipe 50 dengan luasan tanah $7 \times 14 \mathrm{~m}$, tipe 40 dengan luasan tanah $6 \times 12 \mathrm{~m}$, dan tipe 36 dengan luasan tanah $6 \times 10 \mathrm{~m}$.

Analisis terhadap hasil implementasi dari strategi dan taktik konsep produk penting untuk dilakukan guna melihat sejauh mana pengaruh dari strategi atribut produk tersebut dalam mendongkrak nilai penjualan perusahaan. Hasil analisis ini akan berguna sebagai pedoman bagi pihak manajemen perusahaan, khususnya 
perusahaan pengembang perumahan untuk mengambil langkah-langkah kebijakan yang sesuai dan tepat sasaran.

Berdasarkan uraian latar belakang permasalahan di atas penulis tertarik untuk mengambil judul skripsi ini yaitu : " FASILITAS DAN AKSES YANG MEMPENGARUHI KEPUTUSAN KONSUMEN DALAM MEMNENTUKAN PEMBELIAN PERUMAHAN GRIYA AGUNG PERMATA BABAT LAMONGAN "

Berdasarkan latar belakang permasalahan dan batasan penelitian yang telah dijelaskan di atas, maka dapat dirumuskan permasalahan sebagai berikut

a) Apakah terdapat pengaruh fasilitas perumahan terhadap keputusan konsumen melakukan pembelian perumahan Griya Agung Babat Lamongan?

b) Apakah terdapat pengaruh akses perumahan terhadap keputusan konsumen perumahan Griya Agung Permata Babat Lamongan?

c) Variabel manakah yang paling berpengaruh terhadap keputusan konsumen dalam melakukan pembelian perumahan Griya Agung Babat Lamongan?

\section{KAJIAN PUSTAKA}

1. Faktor-faktor yang mempengaruhi keputusan Pembelian Konsumen Menurut sutisna (2010:10) bahwa pengambilan keputusan konsumen merupakan komponen sentral dari model perilaku komsumen, oleh karena itu sangat penting untuk memahami bagaimana proses pengambilan keputusan konsumen berkat keinginan untuk mengetahui kecenderungan perilaku konsumen. Proses keputusan membeli seseorang dimulai dengan pengenalan masalah atau kebutuhan. a. Faktor-faktor yang mempengaruhi keputusan pembelian

Perilaku konsumen selalu berubahubah, hal tersebut dipengaruhi oleh lingkungan sekitar. Oleh karena itu perusahaan harus selalu dapat mengikuti perubahan perilaku konsumen yang mempengaruhi keputusan pembelian supaya produk yang dihasilkan selalu dapat diterima oleh konsumennya. Faktor-faktor yang mempengaruhi keputusan pembelian konsumen itu meliputi faktor internal dan eksternal Sutisna (2001:11):

1) faktor- faktor internal

Faktor internal merupakan faktor dari dalam diri individu. Pengaruh yang dimaksud adalah berkaitan dengan penilaian individu terhadap suatu alternatif produk yang ada yang mengarahkan seseorang untuk mengambil keputusan membeli suatu produk, meliputi:

a) Motivasi

Merupakan istilah internal berhubungan dengan rangsangan internal psikologis seseorang Konsumen maksudnya suatu kondisi yang menyebabkan para konsumen melalui Perilaku mereka. Menurut Kotler dan Armstrong (2010:212) motifasi merupakan "suatu kebutuhan yang secara cukup dirangsang untuk membuat seseorang mencari kepuasan atas kebutuhannya"

Dua teori yang paling populer tentang motifasi adalah teori motifasi Sigmund Freud yang menganggap manusia pada unumnya tidak sadar mengenai kekuatan psikologis yang sebetulnya membentuk perilaku mereka. Dia melihat seseorang tumbuh dan mendesakkan banyak permintaan. Permintaan ini tidak pernah hilang atau dikendalikan secara sempurna, dorongan itu muncul dalam mimpi, terlontar sebagai kata-kata, dalam 
perilaku neurotik dan obsesif, atau akhirnya dalam psikologis. Jadi Freud berpendapat bahwa seseorang tidak benar-benar memahami motifasinya.

Sedangkan menurut Abraham Maslow bahwa kebutuhan manusia diatur dalam satu hierarki, dari yang paling mendesak sampai yang paling tidak mendesak. Dalam urutan kepentingan, ada kebutuhan fisiologi, kebutuhan akan rasa aman, kebutuhan sosial, kebutuhan akan penghargaan dan kebutuhan untuk aktuialisasi diri.

b. Persepsi

Istilah persepsi itu berkaitan dengan cara pandang seseorang terhadap suatu hal, baik itu produk, iklan maupun lingkungan. Maka Kotler dan Amstrong (2010:214) mengatakan bahwa presepsi adalah: "Proses dimana seseorang memilih, mengatur dan menginterpretasikan informasi untuk membentuk suatu gambaran yang berarti mengenai dunia". Dari berbagai uraian diatas dapat dikatakan bahwa persepsi itu ada karena adanya suatu sensasi yang digunakan untuk memberikan arti pada stimuli.

c. Kepribadian

Definisi kepriadian menurut Kotler dan Amstrong (2010:211) kepribadian adalah "Karakteristik psikologis unik seseorang yang menghasilkan tanggapan-tanggapan yang relatif konsisten dan menetap terhadap lingkunganya". Kepribadian Itu juga didasarkan pada karakteristik psikologis yang agak langgeng dan kepribadian kadang dihubungkan dengan konsep diri yang ideal, yang diinginkan oleh individu didalam suatu lingkungan.

d) Belajar

Belajar terjadi sebagai hasil dari pengalaman. Jadi, pernyataan "lebih tua lebih baik" Memang mengandung kebenaran tertentu, karena orang-orang yang berusia lanjut, Mendapatkan kesempatan belajar dari aneka macam pengalaman yang dialami mereka. Maka, Winardi (2008:130), mengatakan bahwa belajar adalah : "Memperoleh dan memiliki sesuatu hal, yang sebelumnya belum kita miliki".

d) Sikap

Mowen, John C dan Michael Minor (2009:319) mendefinisikan bahwa sikap adalah " afeksi atau perasaan untuk atau terhadap sebuah rangsangan" sedangkan Menurut Winardi (2008:136) sikap adalah :"Suatu predisposisi yang dipelajari untuk bereaksi dengan cara yang positif secara konsisten sehubungan dengan obyek tertentu". Sikap itu berkaitan dengan prilaku, dalam arti sikap merupakan hasil dari pengalaman-pengalaman belajar. Sehingga sikap merupakan keadaan yang berlangsung lama dan bukanlah keadaan yang bersifat sementara.

2) Faktor-faktor eksternal

Faktor eksternal merupakan faktor yang berasal dari luar individu karena manusia tidak dapat berdiri sendiri, manusia selalu berinteraksi dengan lingkungannya, sehingga perilakunya juga dipengaruhi oleh lingkungan sekitarnya. Dengan adanya lingkungan yang berbeda-beda mengakibatkan manusia memiliki pandangan, sikap dan kebutuhan yang berbeda-beda. Faktor-faktor eksternal itu terdiri dari :

a) Kebudayaan

Budaya melengkapi orang dengan rasa identitas dan pengertian budaya itu berkaitan dengan perilaku yang diterima didalam masyarakat, sehingga, menurut Engel, Blackwell dan Miniard (2010:65), mengatakan bahwa : "Kebudayaannya itu mengacu pada seperangkat nilai, gagasan, artefak dan simbul bermakna lainya yang membantu individu berkomunikasi, 
membuat taksiran dan melakukan evaluasi sebagai anggota masyarakat'. Budaya merupakan susunan nilai-nilai dasar persepsi, keinginan, dan perilaku yang dipelajari anggota suatu masyarakat dari keluarga dan institusi penting lainnya. Budaya itu tidak mencakup perilaku idionsinkratik yang terjadi sebagai pemecahan sekali saja untuk suatu masalah yang unik. Budaya merupakan penyebab paling mendasar dari keinginan dan perilaku seseorang.

b) Kelas Sosial

Kelas sosial berkaitan dengan kelompok status yang mencerminkan suatu harapan komunitas akan gaya hidup dikalangan masing-masing kelas, jadi menurut Engel, Blackwell dan Miniard (2010: 121), kelas sosial itu mengacu pada : "Pengelompokan orang yang sama dalam perilaku mereka berdasarkan posisi ekonomi mereka dipasar". Sedangkan menurut Kotler dan Armstrong (2001:202) kelas sosial adalah "bagian masyarakat yang relatif permanen dan tersusun rapi yang anggota-anggotanya mempunyai nilai-nilai, kepentingan dan perilaku yang sama".

Kelas sosial tidak dipengaruhi oleh satu faktor saja, tapi ditentukan sebagai satu kombinasi yang kompleks. Dalam beberapa sistem sosialo anggotaanggota dari kelas-kelas yang berbeda menggunakan aturan-aturan tertentu dan tidak dapat mengubah posisi sosial mereka. Kelas sosial juga menunjukkan pemilihan produk dan merk tertentu dalam bidang-bidang pakaian, pralatan rumah tangga dan mobil.

c) Keluarga

Menurut Engel, Blackwell dan Maniard (2010:94), definisi keluarga adalah : "Kelompok yang terjadi dari dua atau lebih orang yang berhubungan melalui darah, perkawinan atau adopsi dan tinggal bersama". Sedangkan menurut Kotler dan Armstrong (2001:204) "keluarga adalah organisasi pembelian konsumen yang paling penting dalam masyarakat, dan pengaruh tersebut telah diteliti secara ekstensif'. Dari definisi diatas dapat dikatakan bahwa keluarga inti, merupakan keluarga yang terdiri dari ayah, ibu dan anakanak yang tinggal bersama, sedangkan keluarga besar merupakan keluarga inti ditambah keluarga-keluarga yang yang lain seperti nenek, kakek, paman dan bibi.

d) Proses

Winardi (2008:51), menyatakan prilaku konsumen sebagai suatu proses merupakan:"Perencanaan, pembelian dan mengkonsumsi produk-produk". Jadi membeli merupakan kegiatan tertentu dari proses tersebut.

b. Proses Keputusan Pembelian Konsumen

Proses keputusan membeli bukan sekedar didasarkan pada berbagai faktor yang dapat mempengaruhi pembeli, melainkan didasarkan pada peranan dalam pembelian dan keputusan untuk membeli. Menurut Assael (2012:16), dalam mengambil keputusan membeli seseorang harus dapat memainkan lima peranan, yaitu

1) Initiator yaitu individu yang mempunyai wewenang atau inisiatif pembelian obyek atau mempunyai wewenang untuk melakukan dan memutuskan sendiri.

2) Influencer yaitu individu yang memutuskan untuk membeli baik sengaja maupun tidak sengaja.

3) Decider yaitu individu yang memutuskan membeli atau tidak membeli, apa yang akan dibeli, 
bagaimana cara membeli, kapan dan dimana membelinya.

4) Buyer yaitu individu yang timbul untuk untuk melaksanakan transaksi pembelian sesungguhnya.

5) User individu yang menggunakan produk jasa yang dibeli.

Diantara berbagai peranan yang dimainkan tersebut terkait erat dengan perilaku konsumen itu sendiri. Adapun proses pengambilan keputusan untuk membeli pada setiap orang sama, hanya seluru proses tersebut tidak selalu dipaksakan oleh setiap orang. Hal ini penting yang berkaitan dengan model prilaku konsumen adalah proses keputusan membeli karena kegiatan membeli yang nampak satu kali merupakan salah satu tahap dari seperangkat tahap dalam proses keputusan membeli.

\section{.2. Pengertian Perumahan}

Rumah adalah bangunan yang berfungsi sebagai tempat tinggal atau hunian dan sarana pembinaan keluarga. Menurut UU No. 4/2002 tentang Perumaham dan Permukiman, mengatakan bahwa Perumahan adalah sekelompok rumah yang berfungsi sebagai lingkungan tempat tinggal atau lingkungan hunian yang dilengkapi dengan sarana dan prasarana lingkungan.

Sammis B. White dalam Catanese dan Snyder (2009), menyatakan dalam pengertian tradisional perumahan merupakan tempat berlindung, tetapi dalam dunia modern perumahan dipergunakan untuk melayani berbagai kebutuhan manusia, menyediakan ruang untuk kegiatan sehari-hari seperti; memasak, makan, bekerja, rekreasi dan tidur. Pengertian ini hanya menekankan kepada kebutuhan fasilitas ruang beserta pengaturannya yang bisa didiami, berfungsi sebagai tempat tinggal untuk melayani kebutuhan manusia dan sarana pembinaan keluarga sesuai dengan jumlah keperluan keluarga dalam satu unit.

Menurut winardi (2008:72), perumahan atau housing mengandung 2 (dua) arti, yaitu sebagai kata benda (produk/komoditi) dan sebagai kata kerja (proses/aktivitas). Perumahan sebagai kata benda menunjukkan bahwa tempat tinggal sebagai komoditi, sedangkan rumah sebagai kata kerja menunjukkan proses dan aktivitas manusia yang terjadi dalam penghunian rumah tersebut. Dengan demikian, rumah tidak hanya dapat dilihat sebagai hasil fisik, tetapi juga sebagai suatu proses yang berkembang dan berkaitan dengan keinginan penghuninya.

\section{METODE PENELITIAN}

Pendekatan Penelitian yang penulis gunakan yaitu pendekatan kuantitatif. Pendekatan kuantitatif adalah pendekatan yang disajikan dalam bentuk angka-angka atau dengan menggunakan rumus-rumus statistik untuk mengatur variabel-variabel penelitian.

$\begin{array}{ccr}\text { Jenis } & \text { penelitian } & \text { Eksplanasi } \\ \text { (ekspalanatory } & \text { research). } & \text { Menurut }\end{array}$
Singarimbun dalam Singarimbun dan Effendi (2009:5) "berpendapat bahwa dalam penelitian penjelasan (eksplanatory Research) peneliti menjelaskan hubungan kausal antara perubah-perubah melalui pengujian hipotesa." Jenis penelitian ini diambil karena digunakan untuk menguji dan menganalisa hubungan dan pengaruh antara variabel-variabel faktor eksternal (perubah bebas) yang mempengaruhi konsumen dalam pengambilan keputusan berkunjung.

\section{Populasi dan sampel}

1. Populasi

Populasi dalam Singarimbun dan Effendi (2005:152) diartikan sebagai jumlah keseluruhan dari unit analisa yang ciri-cirinya akan diduga. Dalam 
penelitian ini yang termasuk populasi adalah seluruh konsumen dari perumahan Griya Agung Permata Babat Lamongan, dengan jumlah penghuni perumahan sebanyak 1001 unit.

2. Sampel

Pengertian sampel adalah " sebagian atau wakil populasi yang di teliti" (Suharsimi Arikunto, 2012:81 ), sehubungan dengan penentuan besarnya sampel, apabila kurang dari 100, maka lebih baik di ambil semua sehingga penelitiannya merupakan penelitian populasi, selanjutnya jika jumlah subyeknya besar dapat diambil antara $10 \%-15 \%$, atau $20 \%-25 \%$ atau lebih, jadi dalam penelitian ini peneliti mengambil sampel $10 \%$ dari populasi sebanyak 100 responden

Adapun Variabel yang akan diteliti

dalam penelitian ini akan dikemukakan teori-teori sebagai berikut:

1). Fasilitas (X1/bebas) adalah Fasilitas adalah unsur utama dalam paket penjualan perumahan saat ini yang terdiri dari sarana dan prasarana yang tidak memikat pandangan namun mendukung kelancaran mobilitas konsumen yang tinggal di lingkungan perumahan. adapun indikator sebagai berikut :

a) kelengkapan fasilitas umum seperti masjid dan mushola.

b) Penataan sarana umum seperti jalan dan parkir.

c) Kesesuaian jumlah fasilitas dengan kebutuhan

2. Promosi (X2/bebas) adalah Akses perumahan merupakan unsur yang berkaitan dengan pelayanan selama berada di dalam lingkungan perumahan dan daya jangkau terhadap pusat-pusat kegiatan masyarakat di lingkungan perumahan

Adapun Indikator sebagai berikut : a) Akses dari dan ke pusat perekonomian dan pemerintahan

b) Waktu tempuh daei dan ke pusat perekonomian dan pemerintahan

c) Akses lokasi perumahan terhadap fasilitas-fasilitas disekitar perumahan

3. Keputusan konsumen (Y/variabel terikat)

Yang menjadi pertimbangan calon konsumen untuk melakukan pembelian setelah terlebih dahulu dinilai secara ekonomis terhadap nilai sekarang maupun nilai investasi di masa mendatang

Adapun indikatornya sebgai berikut :

a) Nilai investasi sesuai dengan kondisi

b) Motivasi untuk memiliki.

\section{Analisis Data}

Analisis data yang dipakai dengan menggunakan SPSS adalah :

1. Uji validitas

Uji validitas adalah ukuran yang menunjukkan tingkat-tingkat kevalidan suatu instrument (Arikunto, 2007 : 157)

2. Uji reabilitas

Reliabilitas menurut (Arikunto, 2012:193) menunjukkan pada suatu pengertian bahwa suatu instrumen dapat dipercaya untuk dapat digunakan sebagai alat pengumpul data karena instrumen tersebut sudah baik, dengan demikian reliabilitas menunjuk pada tingkat keterhandalan sesuatu.

3. Regresi Linier Berganda

Untuk mengukur pengaruh antara variabel bebas terhadap variabel terikat. Persamaan linier berganda dapat dinyatakan dengan rumus dengan Model bebas (X). Model regresi linear ganda atas $\mathrm{X} 1, \mathrm{X} 2 \ldots . \mathrm{Xn}$ sebagai perubah bebas ditunjukkan oleh : (Sudjana, $2009: 69$ ).:

$$
\mathrm{Y}=\mathrm{a}+\mathrm{b} 1 \mathrm{X} 1+\mathrm{b} 2 \mathrm{X} 2+\mathrm{e}
$$


4. Uji hipotesis

a. Uji F

Uji $F$ digunakan untuk menguji apakah ada pengaruh yang signifikan antara variable bebas dengan variable terikat secara bersama-sama bas Sudjana (2009 : 385).

b. Uji T

Uji $\mathrm{T}$ adalah hipotesis yang digunakan untuk mengetahui apakah terdapat pengaruh yang signifikan antara variabel $(\mathrm{X})$ dengan variabel $(\mathrm{Y})$ secara parsial (individu) (Sudjana, 2009 : 108)

\section{HASIL DAN PEMBAHASAN}

1. Karakteristrik Responden

Salah satu langkah dalam rangka analisa data adalah menyajikan penyajian data hasil yang sesuai dengan variable penelitian.

a. Karakteristik Responden berdasarkan jenis kelamin.

Dapat diketahui sebanyak $67,18 \%$ responden berjenis kelamin laki-laki, sedang sebanyak $32,82 \%$ responden berjenis kelamin perempuan.

b. Karakteristik resonden penghasilan perbulan

Responden berdasarkan penghasilan paling banyak dengan Penghasilan Rp 1 juta - Rp 5 juta sebanyak 46 orang, selanjutnya dengan Penghasilan < Rp. 1 juta sebanyak 9 orang, selanjutnya dengan Rp. 6 juta - Rp.10 juta sebanyak 7 orang sedangkan yang memiliki Penghasilan berkisar antara Rp 11 juta - Rp 15 juta sebanyak 3 dan 2 orang yang memiliki Penghasilan berkisar $>15$ juta.

2. Analisis Data

a. Uji Validitas berikut ini
Uji validitas digunakan untuk melihat valid tidaknya masingmasing instrumen dalam variabel Harga Tiket (X1), Promosi (X2) dan Menentukan kunjungan (Y) ke Wisata Bahari Lamongan Dengan taraf signifikan 0,05 (5\%) dalam tabel 4.1

b. Uji Reliabilitas

Uji Reliabilitas bertujuan untuk menguji konsistensi alat ukur (instrumen) yang digunakan, apakah instrumen yang digunakan cukup akurat, stabil atau konsisten. Adapun hasil uji validitas pada pengujian ini untuk masing-masing variabel adalah sebagai berikut:

Tabel 4.1

Rekapitulasi Hasil Uji Validitas

Dan Reliabilitas

Fasilitas (X1)

\begin{tabular}{|l|l|l|l|}
\hline \multicolumn{4}{|c|}{ Validitas } \\
\hline No.Item & R & rTabel & Ket \\
\hline X1.1 & 0.525 & 0,195 & Valid \\
\hline X1.2 & 0.497 & 0,195 & Valid \\
\hline X1.3 & 0.688 & 0,195 & Valid \\
\hline
\end{tabular}

Akses Perumahan (X2)

\begin{tabular}{|l|l|l|l|}
\hline \multicolumn{5}{|c|}{ Validitas } \\
\hline No.Item & R & rTabel & Ket \\
\hline X2.1 & 0.497 & 0,195 & Valid \\
\hline X2.2 & 0.670 & 0,195 & Valid \\
\hline X2.3 & 0.617 & 0,195 & Valid \\
\hline
\end{tabular}

Keputusan Konsumen (Y)

\begin{tabular}{|c|l|l|l|}
\hline \multicolumn{4}{|c|}{ Validitas } \\
\hline No.Item & R & rTabel & Ket \\
\hline Y1 & 0.557 & 0,195 & Valid \\
\hline Y2 & 0,777 & 0,195 & Valid \\
\hline
\end{tabular}

Sumber : SPSS diolah berikut :

Sedangkan Uji Reabilitas Sebagai 
Uji Instrument Reliabilitas

\begin{tabular}{|c|l|l|}
\hline No.Item & $\begin{array}{c}\text { Alpha } \\
\text { Cronbach's }\end{array}$ & Ket \\
\hline X1 & 0,666 & reliabel \\
\hline X2 & 0,683 & reliabel \\
\hline Y & 0,714 & reliabel \\
\hline
\end{tabular}

Sumber : SPSS diolah

Dari tabel diatas dapat disimpulkan

Alpha Cronbach's > 0,60 dapat disimpulakan semua reliabel.

Uji Analisis Regresi

\begin{tabular}{|c|c|c|c|c|c|c|}
\hline \multirow[b]{2}{*}{ Model } & & \multicolumn{2}{|c|}{$\begin{array}{l}\text { Unstandardized } \\
\text { Coefficients }\end{array}$} & \multirow{2}{*}{$\begin{array}{c}\text { Standardized } \\
\text { Coefficients } \\
\text { Beta }\end{array}$} & \multirow[t]{2}{*}{$t$} & \multirow[t]{2}{*}{ Sig. } \\
\hline & & B & $\begin{array}{l}\text { Std. } \\
\text { Error }\end{array}$ & & & \\
\hline \multirow[t]{3}{*}{1} & (Constant) & 6,538 & 1,352 & & 4,836 & ,000 \\
\hline & fasilitas & ,066 & ,077 & ,087 & 2,868 &, 013 \\
\hline & akses &, 115 & .074 & ,156 & 3,561 & ,004 \\
\hline
\end{tabular}

Bentuk persamaan pengaruh variabel $\mathrm{X}$ terhadap variabel $\mathrm{Y}$ adalah sebagai berikut

$\mathrm{Y}=6,538+0,066 \mathrm{X} 1+0,115 \mathrm{X} 2$, yang diartikan sebagai berikut :

$\mathrm{a}=6,538$, merupakan intercept yang berarti apabila variabel bebas yang mempengaruhi $=0$, maka hasil yang di peroleh dari keputusan konsumen adalah sebesar 6,538.

$\mathrm{b} 1=0,066$, artinya variabel fasilitas mempunyai pengaruh yang positif terhadap keputusan konsumen, atau apabila sikap konsumen meningkat sebesar 1 poin, maka akan dikuti peningkatan keputusan konsumen sebesar 0,066 dan menganggap variabel lainnya konstan.

b2 = 0,115, artinya bahwa akses perumahan mempunyai pengaruh yang positif terhadap keputusan konsumen, atau apabila sikap konsumen meningkat sebesar 1 poin, maka akan di ikuti peningkatan keputusan kosumen sebesar 0,115 dan menganggap variabel lainnya konstan.
Uji Hipotesis

a. Uji F

ANOVA(b)
\begin{tabular}{|l|l|r|r|r|r|r|}
\hline \multicolumn{2}{|l|}{ Model } & & Sum of & & & \\
\hline 1 & & Squares & df & Mean Square & F & Sig. \\
\hline & Regression & 2,210 & 2 & 1,105 & 17,392 &, $011(\mathrm{a})$ \\
& Residual & 61,630 & 97 &, 635 & & \\
& Total & 63,840 & 99 & & & \\
\hline
\end{tabular}

a Predictors: (Constant), akses, fasilitas

b Dependent Variable: keputusan

hasil analisis di peroleh $\mathrm{F}$ Hitung sebesar 17,392 sedang nilai $F$ Tabel sebesar 2,70 jadi di peroleh asumsi $\mathrm{F}$ Hitung > F Tabel . Sedangkan pada taraf signifikan $\alpha=0,05$ dengan Probabilitas (Sig.) sebesar $0,011<0,05$, maka di peroleh asumsi bahwa Ho diterima dan Ha di tolak, sehingga variabel fasilitas (X1) dan akses perumahan (X2) secara bersama-sama memiliki pengaruh yang nyata terhadap keputusan konsumen (Y)

b. Uji T

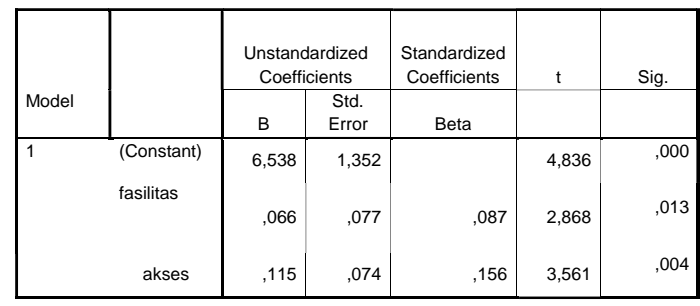

Berdasarkan tabel diatas menunjukkan bahwa :

a) Hasil perhitungan (SPSS) nilai koefisien regresi fasilitas (b1) sebesar 0,066 . hal ini menunjukkan besarnya pengaruh fasilitas (X1) terhadap keputusan konsumen (Y), artinya fasilitas yang disediakan pihak pengembang mempunyai pengaruh yang cukup signifikan terhadap keputusan konsumen

b) Begitupun dengan hasil analisis Uji $\mathrm{T}$ diperoleh nilai $\mathrm{T}$ Hitung sebesar 2,868 > T Tabel sebesar 1,660, sedangkan pada taraf signifikan $\alpha$ $=0,05$ diperoleh 0,013 lebih kecil 
dari 0,05, maka diperoleh asumsi bahwa Ha di tolak dan Ho di terima, sehingga teruji variabel fasilitas (X1) mempunyai pengaruh yang cukup signifikan terhadap keputusan konsumen.

c) Sedangkan hasil analisis Uji $\mathrm{T}$ di peroleh nilai $\mathrm{T}$ Hitung sebesar 3,561, > nilai $\mathrm{T}$ Tabel sebesar 1,660. Maka di peroleh hasil $\mathrm{T}$ Hitung $>\mathrm{T}$ Tabel. pada taraf signifikan $\alpha=0,05$, diperoleh dengan probabilitas sebesar 0,004 lebih kecil dari 0,05, maka di peroleh asumsi bahwa Ha di tolak dan Ho diterima, sehingga teruji variabel akses perumahan (X2) memiliki pengaruh yang signifikan terhadap keputusan konsumen.

\section{SIMPULAN DAN SARAN}

Berdasarkan analisa data dapat disimpulkan sebagai berikut :

Maka dapat ditarik kesimpulan sebagai berikut :

a) bahwa fasilitas maupun akses perumahan memiliki pengaruh yang cukup kuat terhadap keputusan konsumen dalam membeli produk perumahan Griya Agung Permata Babat Lamongan, tapi diantara kedua variabel tersebut, variabel akses perumahan memiliki pengaruh yang lebih dominan.

b) Fasilitas maupun akses perumahan yang disediakan oleh pengembang dianggap masih dipengaruhi faktorfaktor lain selain fasilitas dan akses perumahan, semisal harga, promosi, dan sebagainya dianggap memiliki pengaruh terhadap keputusan konsumen dalam membeli produk perumahan Griya Agung Permata Babat Lamongan

\section{Saran}

Adapun saran-saran tersebut adalah sebagai berikut : a) Sebaiknya pihak pengembang terus meningkatkan kualitas akses perumahan, agar dapat lebih dijadikan bahan pertimbangan bagi konsumen dalam mengambil keputusan untuk membeli produk perumahan Griya Agung Permata Babat Lamongan, hal ini bisa dilakukan dengan penyediaan sarana transportasi umum.

b) Sebaiknya pihak pengembang terus meningkatkan fasilitas perumahan untuk meningkatkan keputusan pembelian konsumen. Hal ini dapat dilakukan dengan melengkapi dan peningkatan kualitas dari fasilitas yang ada, khususnya pada penyediaan air bersih.

Demikian simpulan dan saran yang bisa penulis kemukakan dengan harapan bahwa apa yang penulis uraikan dapat membantu dalam memberi masukan berupa empiris yang dapat di gunakan untuk memahami bahwa fasilitas dan akses perumahan sedikit banyak juga memiliki pengaruh terhadap keputusan konsumen dalam melakukan pembelian produk perumahan Griya Agung Permata Babat Lamongan.

\section{DAFTAR PUSTAKA}

Assael Henry (2012) Consumer Behavior and Marketing Action. Fourth Edistion. PWS-KENT Publising Company. Boston. Massachutts.

Arikunto , Suharsimi, 2012 .Prosedur Penelitian, Cetakan 20, PT Rineka Cipta. Jakarta.

As'ad, 2010. Analisa Pertimbangan Pribadi Terhadap Pembelian Tipe Rumah di Perumahan Katon Asri Surakarta, Skripsi UNS solo 
Efendi, 2006. Analisa Lima Faktor

Terhadap Pembelian Rumah

Sederhana dan Sangat

Sederhana, Skripsi USU

Gitosudarmo, Indriyo. 2008. Manajemen

Pemasaran Edisi kelima.

Yogyakarta: BPFE.

Kotler, Philip. 2013. Manajemen

Pemasaran Jilid 6. Jakarta:

Prenhallindo.

Kotler, Phillip. 2010. Manajemen

Pemasaran. Jakarta:

Prenhallindo.

Kotler, Philip dan Gary Armstrong. 2010.

Prinsip-prinsip Pemasaran jilid

1. edisi kededelapan. Jakarta:

Erlangga

Rangkuti,2011. Metode Penelitian

Kuantitatif Kualitatif, Bandung:

CV. Alfabeta

Sutisna, 2011. Perilaku Konsumen dan

Komunikasi Pemasaran. PT

Gramedia Pustaka Utama,

Jakarta.

Sudjana, 2009. Teknik Analisis Regresi dan Korelasi bagi Para Peneliti. Bandung. Penerbit: Tarsito

Subrata,2008 Analisa Faktor yang

Mempengaruhi Permintaan

Rumah Sederhana dan Sangat

Sederhana, Skripsi Unmuh

Medan

Siti Inganah ,2013. Faktor-faktor yang

Mempengaruhi Keputusan

Konsumen Dalam Pembelian

Rumah Mewah, Skripsi Unibraw

Malang

Winardi, 2008. Marketing dan Perilaku

Konsumen. PT Mandar Maju,

Bandung. 